\title{
KOMPARASI PERFORMA JARINGAN ANTARA PENYEDIA LAYANAN SELULER 4G LTE DI AREA KOTA YOGYAKARTA
}

\author{
Ari Sugiharto, Ikrima Alfi
}

Teknik Komputer - Universitas Teknologi Yogyakarta

Yogyakarta

ari.sugiharto@uty.ac.id

\begin{abstract}
Cellular telecommunication technology has grown to the fourth generation, namely the $4 G$ network. Although almost all operators of cellular telecommunication service providers have stated that they are ready with the $4 G$ network, in reality, not all areas in the city of Yogyakarta are covered by $4 G$ network services. This condition complained by many users. The performance of the $4 G$ network in the area of Yogyakarta needs to be further investigated so that its utilization is more optimal and does not disappoint the network users. This study analyzes the performance of $4 G$ LTE networks from various cellular phone service operators in the area of Yogyakarta city, represented by two operators. Performance parameters measured are Reference Signal Received Power (RSRP) and Reference Signal Received Quality (RSRQ). In this study a drive test was conducted to determine cellular signal quality in various areas representing dense urban, suburban and urban areas in the city of Yogyakarta. From the results of the drive test measurements, the conclusion of the test results for operator A, RSRP max value $-57 \mathrm{dBm}$, RSRP min -117 dBm, RSRP average 85.35dBm, RSRQ max -4 dBm, RSRQ min -23 dBm, and RSRQ average -13.02 dBm. Whereas for operator $B$ obtained the RSRP max value is $-51 \mathrm{dBm}$, RSRP min -105 dBm, RSRP average $76.92 \mathrm{dBm}, R S R Q \max -4 \mathrm{dBm}, R S R Q$ min $-21 \mathrm{dBm}$, and RSRQ average $-8.94 \mathrm{dBm}$.
\end{abstract}

Keyword: 4G LTE, Network Performance, RSRP, RSRQ.

\begin{abstract}
Abstrak
Teknologi telekomunikasi seluler telah berkembang ke generasi keempat, yaitu jaringan 4G. Meskipun hampir semua operator penyedia layanan telekomunikasi seluler telah menyatakan bahwa mereka siap dengan jaringan 4G, pada kenyataannya, tidak semua area di kota Yogyakarta tercakup oleh layanan jaringan 4G. Kondisi ini dikeluhkan oleh banyak pengguna. Kinerja jaringan $4 \mathrm{G}$ di wilayah Yogyakarta perlu ditelusuri lebih lanjut sehingga pemanfaatannya lebih optimal dan tidak mengecewakan pengguna jaringan. Penelitian ini menganalisis kinerja jaringan 4G LTE dari berbagai operator layanan telepon seluler di wilayah Kota Yogyakarta, diwakili oleh dua operator. Parameter kinerja yang diukur adalah Daya Sinyal Referensi yang Diterima (RSRP) dan Kualitas Referensi Sinyal yang Diterima (RSRQ). Dalam studi ini drive test dilakukan untuk menentukan kualitas sinyal seluler di berbagai daerah yang mewakili daerah perkotaan, sub urban dan perkotaan padat di kota Yogyakarta. Dari hasil pengukuran tes drive, kesimpulan dari hasil tes untuk operator A, RSRP nilai maks $-57 \mathrm{dBm}$, RSRP min $-117 \mathrm{dBm}$, RSRP rata-rata $-85.35 \mathrm{dBm}$, RSRQ max -4 $\mathrm{dBm}$, RSRQ min $-23 \mathrm{dBm}$, dan RSRQ rata-rata $-13,02 \mathrm{dBm}$. Sedangkan untuk operator B diperoleh nilai maks RSRP $-51 \mathrm{dBm}$, RSRP min $-105 \mathrm{dBm}$, RSRP rata-rata 76,92 dBm, RSRQ max $-4 \mathrm{dBm}$, RSRQ min $-21 \mathrm{dBm}$, dan RSRQ rata-rata $-8,94 \mathrm{dBm}$.
\end{abstract}

Kata Kuci : 4G LTE, Kinerja Jaringan, RSRP, RSRQ. 


\section{Pendahuluan}

\subsection{Latar Belakang}

Semakin majunya kehidupan manusia di era globalisasi seperti sekarang ini membuat teknologi mengalami kemajuan yang pesat khususnya di teknologi telekomunikasi seluler. Telekomunikasi seluler memudahkan manusia untuk menerima ataupun mengirimkan sebuah informasi secara cepat dan efisien. Untuk sekarang ini teknologi telekomunikasi sudah mengalami perkembangan sampai generasi ke empat yaitu jaringan 4G [1].

Penggunaan HP (handphone) sebagai perangkat telekomunikasi seluler juga semakin meningkat. Menurut [2] jumlah pengguna HP di Indonesia semakin meningkat, terakhir menduduki peringkat 4 dunia yaitu 285 juta pengguna, dengan 45,5 juta diantaranya berada di kota-kota besar serta pada jaringan $3 \mathrm{G} / 4 \mathrm{G}$. Juga terjadi pergeseran tren penggunaan HP dari alat komunikasi berbasis layanan suara/teks, menjadi alat komunikasi berbasis layanan pertukaran data, yang memang didukung oleh perkembangan teknologi jaringan seluler 4G.

Adanya perkembangan teknologi seluler ke jaringan $4 \mathrm{G}$ ternyata juga memberikan dampak positif terhadap kinerja perusahaan operator. Menurut [3] berdasarkan data kinerja dari 5 perusahaan telekomunikasi seluler yang terdaftar di BEI, dengan adanya perkembangan teknologi 4G sejak tahun 2014, XL dan Smartfren adalah 2 besar yang merasakan dampak positif pada pertumbuhan bisnisnya. Sementara untuk 3 operator lainnya belum terlalu signifikan dampak positif yang dirasakan sejak mengembangkan layanannya ke jaringan $4 \mathrm{G}$.

Meskipun pihak operator layanan seluler terus berusaha meningkatkan cakupan jaringan 4G di Indonesia, namun pada prakteknya di kota-kota besar khususnya di Yogyakarta, hingga pertengahan tahun 2016 belum semua wilayah dapat menggunakan jaringan 4G [4]. Gambar 1 dan 2 menunjukkan klaim cakupan layanan jaringan 4G oleh operator seluler XL dan Smartfren di area Yogyakarta, yang pada kenyataannya di lapangan masih belum merata. Ketidak merataan pelayanan jaringan $4 \mathrm{G}$ ini banyak dikeluhkan oleh pengguna, termasuk pelanggan operator XL dan Smartfren [5]. Padahal tingkat kepuasan pengguna akan kualitas layanan jaringan $4 \mathrm{G}$ sangat berpengaruh terhadap kinerja positif keuangan perusahaan operator [6]. Jika layanan 4G tidak ditingkatkan, beresiko mengakibatkan kekecewaan pelanggan, sehingga berpindah ke lain operator. Pertumbuhan positif kinerja keuangan perusahaan operator bisa terhenti karena kurang optimalnya layanan jaringan $4 \mathrm{G}$.

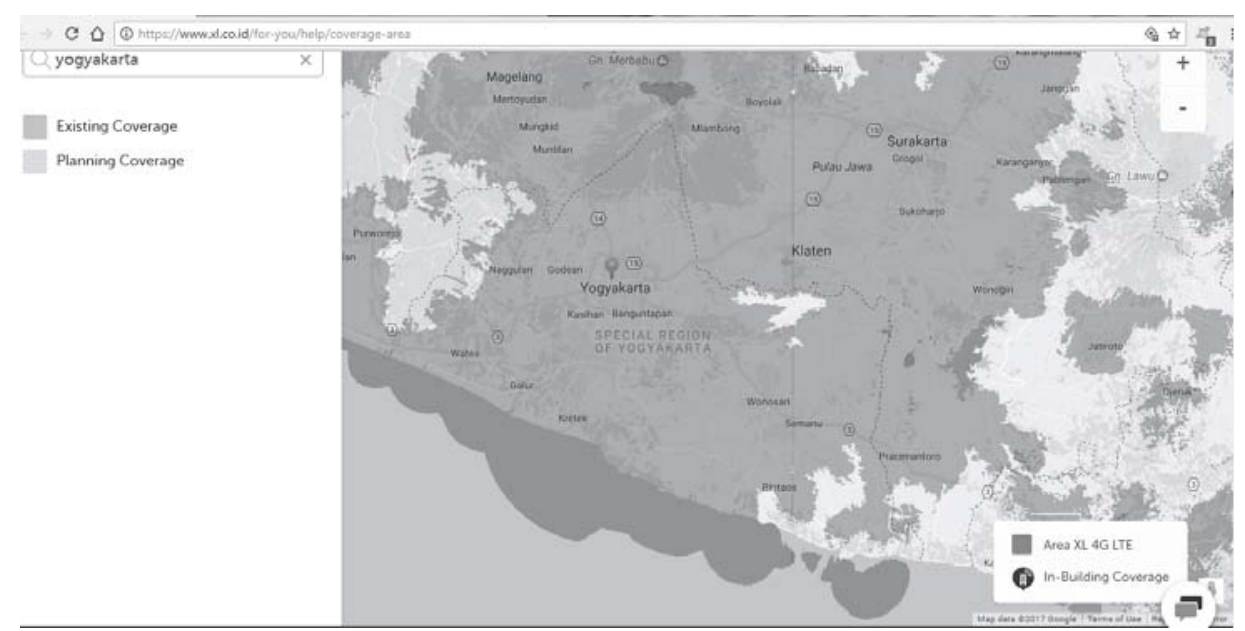

Gambar 1:Klaim Cakupan Layanan Jaringan 4G Operator Seluler XL di Area Yogyakarta (Sumber: www.xl.co.id diakses 31 Maret 2018) 


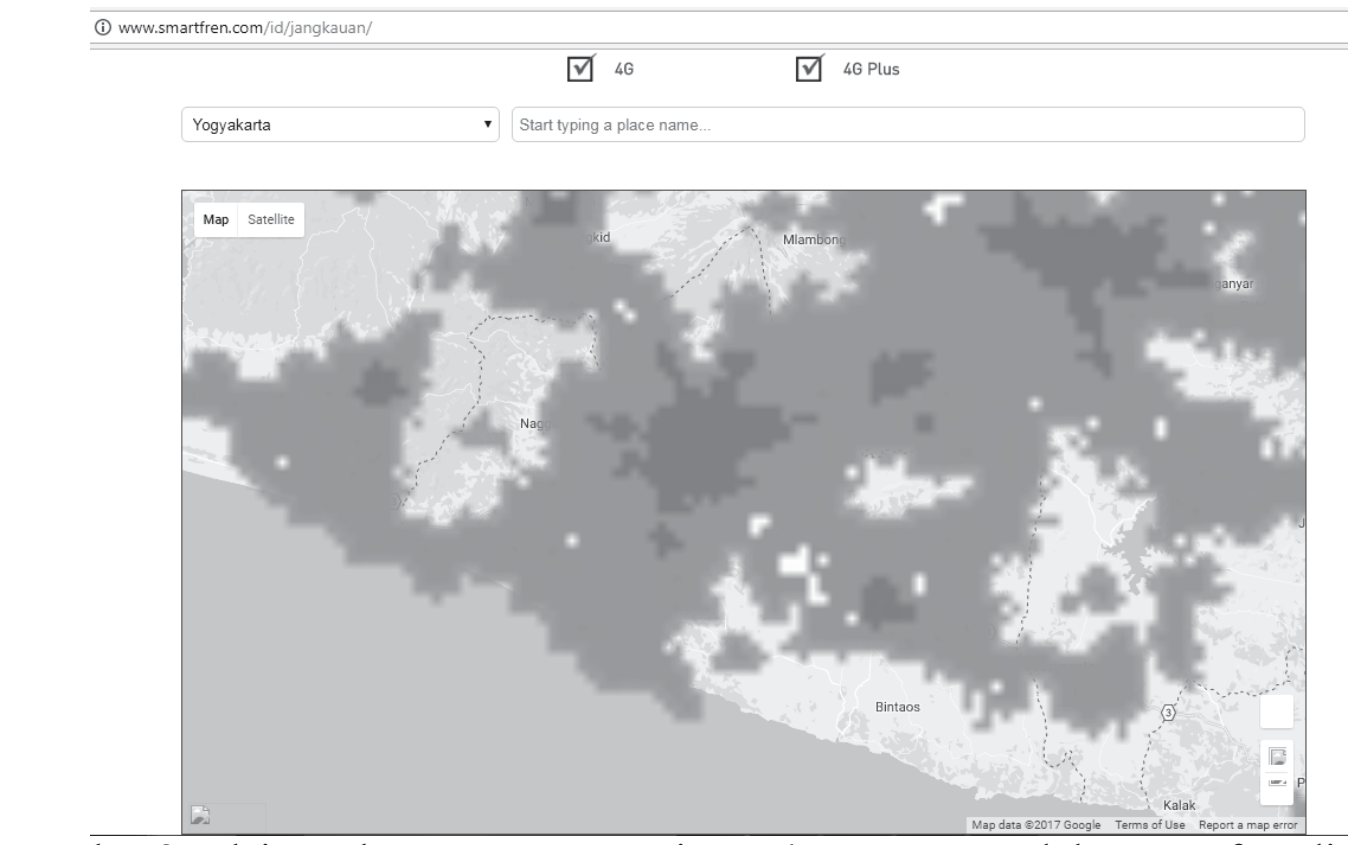

Gambar 2. Klaim Cakupan Layanan Jaringan 4G Operator Seluler Smartfren di Area Yogyakarta

(Sumber: www.smartfren.com diakses 31 Maret 2018)

Adanya perbedaan antara klaim cakupan layanan jaringan $4 \mathrm{G}$ oleh operator dengan pengalaman pengguna di lapangan diakibatkan karena klaim tersebut berdasarkan prediksi perhitungan secara teknis. Sedangkan kondisi di lapangan amat beragam, tergantung berbagai kondisi. Antaralain adalah kepadatan pengguna, topografi wilayah, serta lokasi pengguna. Berdasarkan latar belakang tersebut, maka performa jaringan $4 \mathrm{G}$ yang telah dibangun di Yogyakarta perlu diteliti lebih lanjut supaya penggunaannya lebih efisien dan tidak mengecewakan pelanggan.

\subsection{Tinjauan Pustaka}

Penelitian yang pernah dilakukan untuk menganalisa kualitas layanan seluler, antara lain oleh [7]. Penelitiannya membahas tentang kualitas jaringan 4G, dengan standar QoS (Quality of Services) berupa penerimaan paket data oleh modem USB. Hasil yang diperoleh kurang dapat memberikan gambaran performa layanan, karena tidak mencakup jaringan komunikasi suara dan teks, serta tidak mencakup standar yang umum digunakan oleh operator untuk mengukur kualitas jaringan layanan seluler (drive test key performance indicator/KPI). Sehingga belum dapat digunakan untuk perencanaan pengembangan layanan jaringan.

Penelitian kedua oleh [8], telah menganalisa tentang kualitas layanan jaringan seluler dengan standar KPI. Namun penelitiannya dilakukan pada jaringan UMTS, dengan lokasi di Denpasar Timur, serta khusus untuk menara BTS yang terletak di puncak gedung (rooftop).

Penelitian berikutnya oleh [5] dalam jurnal yang berjudul Pengukuran dan Analisis Sinyal RF pada Penerima Seluler di Area Surabaya, melakukan pengukuran sinyal selular 3G di area Surabaya dan menggunakan ARIMA $(2,0,1)$ dalam pemodelan jaringan.

\subsection{Parameter Performa Radio LTE}

Optimasi jaringan merupakan kegiatan yang dilaksanakan untukmeningkatkan kinerja performansi suatu jaringan seluler. Optimasi dilakukan untuk mendapatkan kualitas jaringan yang terbaik dengan menggunakan data yang tersedia seefisien mungkin. Optimasi jaringan memiliki parameter yang harus diperhatikan. Peningkatan performasi dari parameter optimasi 
akan berpengaruhterhadap kinerja suatu jaringan. Beberapa parameter performa pada jaringan 4G LTE adalah sebagai berikut [1]:

a. Reference Signal Received Power (RSRP)

RSRP didefinisikan sebagai rata-rata linear daya yang dibagikan pada resource elements yang membawa informasi reference signal dalam rentang frekuensi bandwidth yang digunakan. Fungsinya sendiri yaitu untuk memberikan informasi ke UE (user equipment) mengenai kuat sinyal pada satu sel berdasarkan perhitungan path loss dan mempunyai peranan penting dalam proses handover dan cel selection-reselection. RSRP dapat dirumuskan pada persamaan 1.

$\mathrm{RSRP}=\mathrm{RSSI}(\mathrm{dBm})-10 \mathrm{x} \log (12 \mathrm{xN})$

\section{RSSI : Received Strength Signal Indicator}

b. Reference Signal Received Quality (RSRQ)

RSRQ sangat berhubungan dengan RSRP dan RSSI. Received Signal Strength Indication (RSSI) adalah ukuran power bandwidth termasuk serving cell power, Noise, dan interference power. RSRQ didefinisikan sebagai ratio antara jumlah N RSRP terhadap RSSI atau bisa ditulis pada persamaan 2 .

$$
R S R Q=\frac{N \times R S R P}{R S S I}
$$

Satuan dari RSRQ adalah dB dan nilainya selalu negative dikarenakan RSSI selalu lebih besar dibandingkan dengan N x RSRP. RSRQ dapat meranking performansi kandidat sel dalam proses cel selection-reselection dan handover berdasarkan kualitas sinyal yang diterima.

\subsection{Drive Test}

Drive Test dilakukan sebagai bagian dari optimalisasi jaringan sinyal radio. Pekerjaan ini bertujuan mengumpulkan informasi yang nyata di lapangan. Informasi tersebut adalah keadaan nyata sinyal radio dari suatu titik alat pemancar/penerima.

\subsection{Nemo}

Nemo adalah perangkat lunak untuk membantu pengujian jaringan telekomunikasi (drive test). Terdiri dari pasangan Nemo Handy, yaitu program yang ditanam pada piranti mobile untuk melakukan pengukuran sinyal di lapangan. Serta Nemo Outdoor dan Analyze untuk menganalisa hasil dari pengukuran sinyal tersebut.

\section{Metode}

Penelitian ini dilakukan di laboratorium elektronika kampus UTY untuk perhitungan dan analisa data, serta seputar area wilayah kota Yogyakarta untuk lokasi pengambilan data pengukuran drive test.

Tahapan pada metode penelitian ini adalah:

a. Studi literatur

Meriset dasar teori dari konsep dasar mengenai jaringan seluler serta berbagai metode yang digunakan untuk mengukur performa dan perencanaan pembangunan jaringan, khususnya 4G LTE.

b. Pengumpulan data 
Pengukuran data riil di lapangan dengan drive test.

c. Pengolahan data

Setelah diperoleh hasil drive test menggunakan smartphone, data kemudian diolah untuk memperoleh masukan guna mengukur kualitas layanan jaringan dan kualitas sinyal. Hasilnya kemudian untuk memperoleh standar parameter performa layanan jaringan 4G.

d. Analisa

Dari hasil olah data kemudian dibandingkan dengan nilai yang terukur di lapangan. Maka akan diperoleh hasil analisa mengenai performansi layanan jaringan, dengan acuan ukur performa adalah nilai RSRP dan RSRQ untuk tiap operator.

e. Kesimpulan

Pada akhir penelitian diharapkan diperoleh kesimpulan mengenai kualitas layanan jaringan 4G LTE yang ada di kota Yogyakarta.

\section{Hasil dan Pembahasan}

\subsection{Hasil Pengukuran Parameter}

Data diperoleh dari pengukuran drive test pada rute yang melewati area kota Yogyakarta seperti pada gambar 3.

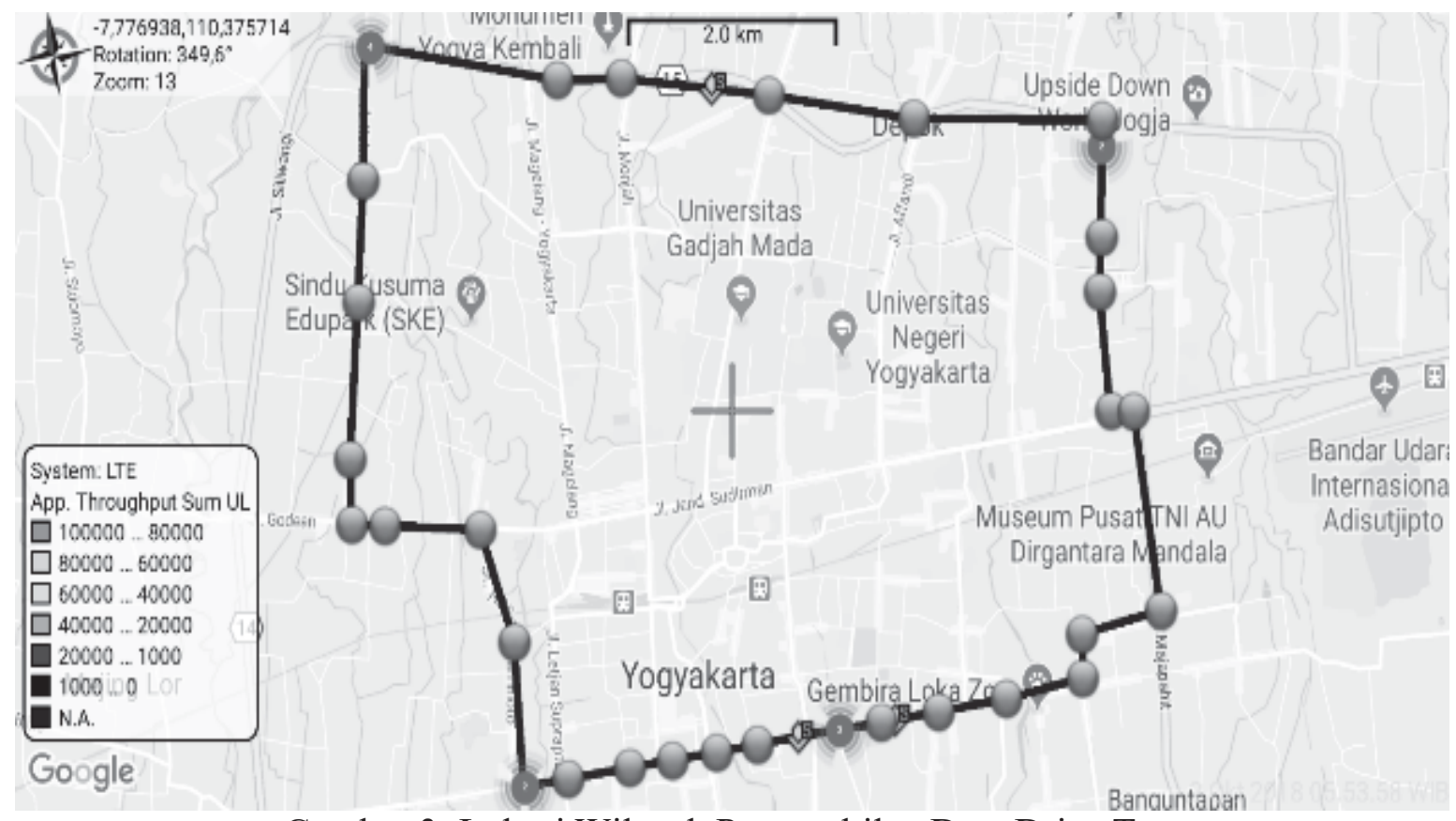

Gambar 3. Lokasi Wilayah Pengambilan Data Drive Test

Hasil pengukuran drive test pada kedua operator seperti pada gambar 4 dan 5 . 


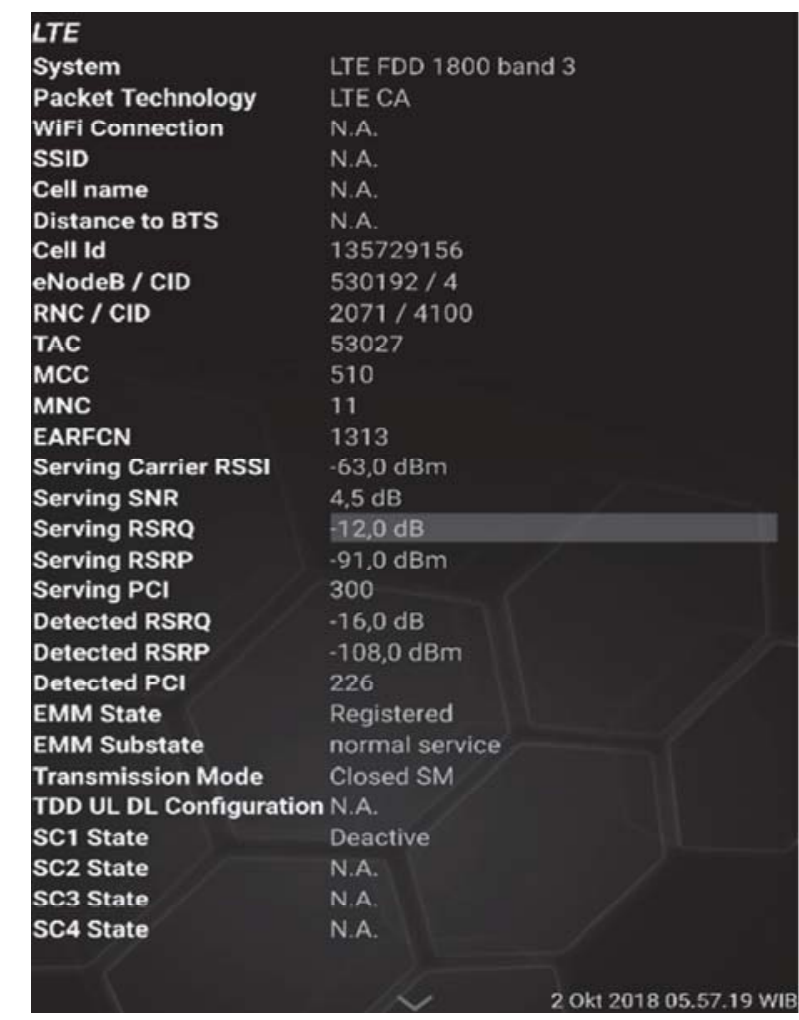

Gambar 4. Summary Hasil Drive Test Operator A

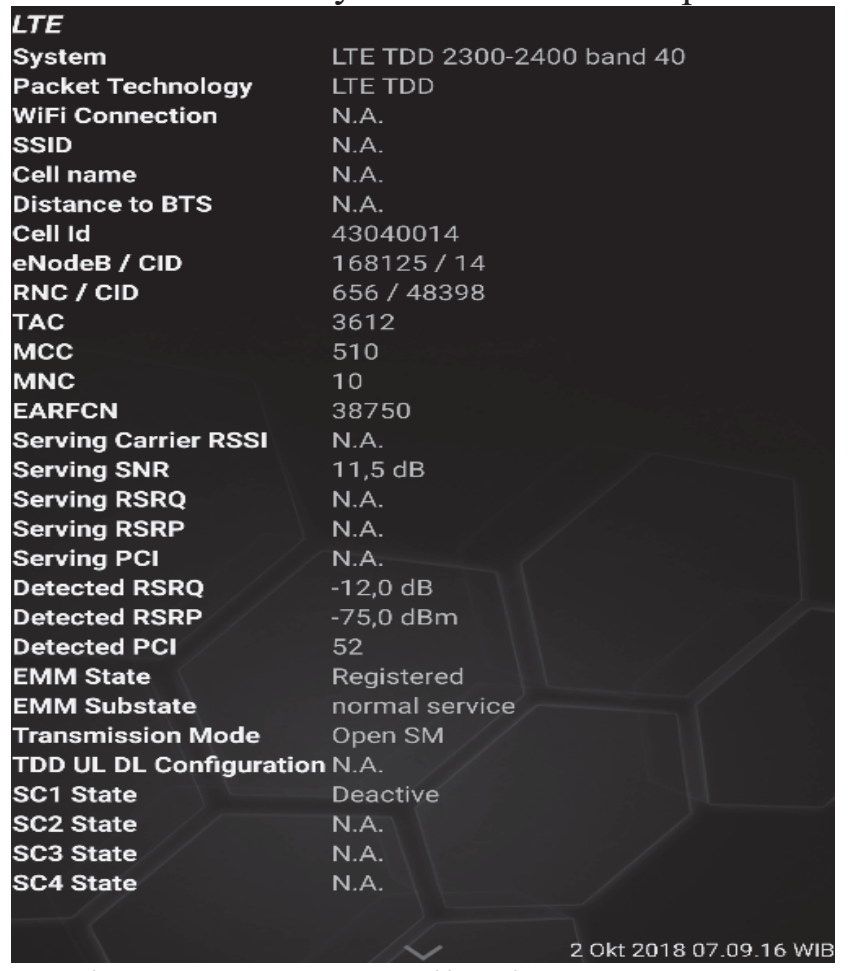

Gambar 5. Summary Hasil Drive Test Operator B

\subsection{Analisa}

Dari hasil pengukuran dua operator tersebut, dapat diolah menggunakan software sehingga dapat diperoleh kesimpulan angka seperti pada gambar 6 dan 7.

Dari hasil pengukuran drive test, diperoleh untuk operator A, nilai RSRP max 57dBm, RSRP min -117 dBm, RSRP rata-rata -85,35 dBm, RSRQ max -4 dBm, RSRQ min - 
$23 \mathrm{dBm}$, serta RSRQ rata-rata $-13,02 \mathrm{dBm}$. Sedangkan untuk operator B diperoleh nilai RSRP max $-51 \mathrm{dBm}$, RSRP min $-105 \mathrm{dBm}$, RSRP rata-rata 76,92 dBm, RSRQ max $-4 \mathrm{dBm}$, RSRQ min $-21 \mathrm{dBm}$, serta RSRQ rata-rata $-8,94 \mathrm{dBm}$.

Adanya perbedaan nilai hasil pengukuran dan analisa untuk kedua operator jika dilihat dari faktor eksternal operator adalah persebaran demografi pengguna layanan di seluruh area kota, serta topografi bangunan di sekitar BTS tiap operator. Area dengan hasil pengukuran performa cukup baik, berada pada wilayah yang kepadatan penduduknya lebih rendah serta jumlah bangunan yang lebih sedikit. Sedangkan pada wilayah yang jumlah penduduk lebih padat dan banyak ditemui bangunan, hasil pengukuran kinerja lebih rendah. Hal ini mempengaruhi kepuasan konsumen pengguna layanan jaringan 4G jika berada pada area yang padat penduduk dan jumlah bangunan cukup banyak.

\begin{tabular}{|l|}
\hline 9baeb74c-ad46-4dc0-b201-0d2276d017a4 \\
Device ID;1 \\
Device Label;Handy \\
Device Name;samsung/SM-N920I \\
RSRP max;-57.000000 \\
RSRP min;-117.000000 \\
RSRP avg;-85.347626 \\
RSRQ max;-4.000000 \\
RSRQ min;-23.000000 \\
RSRQ avg;-13.021948 \\
\hline Gambar 6. Hasil Analisa Operator A \\
\hline 88a5913f-09d8-454e-ab12-937577a5dceb \\
Device ID;1 \\
Device Label;Handy \\
Device Name;samsung/SM-N920I \\
RSRP max;-51.000000 \\
RSRP min;-105.000000 \\
RSRP avg;-76.916054 \\
RSRQ max;-4.000000 \\
RSRQ min;-21.000000 \\
RSRQ avg;-8.943258 \\
\hline Gambar 7. Hasil Analisa Operator B \\
\hline
\end{tabular}

\section{Simpulan}

Hasil pengukuran drive test pada penelitian ini dapat memberikan kesimpulan bahwa kualitas nilai parameter layanan operator seluler dapat berbeda tiap jaringan, meskipun pada wilayah layanan yang sama. Hasil komparasi parameter performa memperlihatkan bahwa kualitas jaringan dipengaruhi oleh berbagai faktor, seperti kecepatan gerak mobile unit, kerapatan pengguna, serta kondisi topografi yang mempengaruhi line of sight sinyal seluler. Tindakan lanjutan dari hasil analisa pengukuran penelitian ini, disarankan untuk selanjutnya dilakukan perencanaan pengembangan optimasi jaringan oleh operator seluler dalam rangka meningkatkan pelayanan, berdasar data hasil analisa kinerja layanan di lapangan.

\section{Daftar Pustaka}

[1] Wardhana L. 2014. 4G Handbook Volume 1. Floatway Systems.

[2] Wandira, Ayu L. W., dan Edwar M. 2016. Pengaruh Kualitas Produk Dan Promosi Terhadap Keputusan Pembelian Produk Smartfren Andromax 4G/LTE Pada Mahasiswa 
Fakultas Ekonomi Universitas Negeri Surabaya. Jurnal Pendidikan Tata Niaga UNESA. Vol 1:1-11.

[3] Setiadi A. 2016. Peran 4G LTE Dalam Perkembangan Kinerja Keuangan Perusahaan Telekomunikasi di Indonesia. Tugas Akhir. Fakultas Ekonomi dan Manajemen Institut Pertanian Bogor.

[4] Wibisono L. E. 2016. Pengaruh Kualitas Produk, Kualitas Layanan dan Persepsi Harga Terhadap Kepuasan Pelanggan Pengguna 4G XL di Yogyakarta. Tugas Akhir. Fakultas Ekonomi Universitas Negeri Yogyakarta.

[5] Basri M. O. S. dan Mauludiyanto A. 2016. Pengukuran dan Analisis Sinyal RF pada Penerima seluler di Area Surabaya. Prosiding SENTIA. Volume 8: D15-D21.

[6] Sari D. D. 2016. Analisis Pengaruh Kualitas Produk, Kualitas Pelayanan dan Harga Terhadap Kepuasan Konsumen (Studi Kasus Pada Konsumen SIM CARD GSM Prabayar XL di Kota Yogyakarta). Tugas Akhir. Fakultas Ekonomi Universitas Negeri Yogyakarta.

[7] Mahanani G. S. 2016. Analisis dan Pengujian di Jaringan 3G dan 4G Dalam Layanan Quality of Servicees (QoS). Tugas Akhir. Fakultas Sains dan Teknologi Universitas Islam Negeri Yogyakarta.

[8] Pramanda P. P. W., Sudiarta, P. K. dan Indra N. E. R. 2016. Analisis Jaringan UMTS pada Menara Rooftop dengan Menggunakan Software TEMS Investigation dan GNettrack Pro. E-journal SPEKTRUM. Vol.3:47-53. 